\title{
Physical and Psychological Violence in High Schools, Teaching their Treatment
}

\author{
Zamira Gjeleshi \\ zgjeleshi@gmail.com \\ PhD cand. UET/ Pedagogy /Albania \\ Defrim Kaleci \\ DAR / Dibër/Albania \\ Etleva Miftari \\ Student University of Tirana /Albania
}

\section{DOI:10.5901/mjss.2014.v5n19p546}

\begin{abstract}
During the last two decades, educational reforms have had to do with programs, texts, achieving objectives, the new high school curriculum, M.SH and teaching models. A hidden issue, but more disturbing recent violence in Albanian schools. It is clear that violence prevails not only in school, but there is a lack of understanding as to the causes underlying this phenomenon, the impact it has on the lives of children and possible ways to tackle this problem, which affects thousands of students in days. Since the bullying day - the day of cases is increasing, so is the duty of all responsible institutions, to investigate this negative phenomenon. Measures to prevent adding professionalism, sound education and the right professional to advice on the youth and adults. Children do not lose their human rights by overcoming the threshold of the school. Thus, for example, education must be provided in a manner that respects the inherent dignity of the child, giving the child the opportunity to express his views freely and to participate in school life. Education should be provided in a manner that respects the strict limits on discipline and promote a culture of against violence in school. The talent is developed skills in the highest degree. This gifted child born should be supported to enable him to be great in science, art, social life, etc.. Should know the nature of the students and enable them cope with life's challenges. The choice of profession and career are two of the most important decisions for human life. Inadvertently and unconsciously through violence we enslave drowned talent and great scientist, famous artist, military strategist, I object to violence because when it appears and do good, the good is only temporary, and when it is evil, evil is eternal!
\end{abstract}

Keywords: Violence, defense system of children, law, education, teen dating violence, bullying

\section{Introduction}

This study builds on previous findings of many scientific materials and know their values. What I want to do through this study is to go beyond current information, to explore ways to further a comprehensive approach and existing activities.

I saw the need to review, gather, to consolidate and update the literature to my knowledge on this issue through group discussions, interviews, discussions with key informants and focus on the issue as it is seen by children reaching a good level of understanding as to the reasons that lie at the basis of school violence, which is an issue that has just begun to be addressed.

Violence against children is the worst form of violence and intolerable to a human being, and this phenomenon affects all societies, systems and countries, whether wafer, developing or developed, and is extended to family, school, road and society.

It is no accident that the United Nations has decided to schedule two consecutive days of remembrance and awareness for the whole world, 19 November - World Day for Prevention of Abuse and Violence against Children and 20 November International Day for the Rights of Child "

What is the physical and psychological violence?

When exercising national and international laws to protect children? 
Where should act Child Protection System, programs, education policy, civil society and the media to physical and psychological violence?

Why can't stop violence in schools, where we can send humans to the moon?

How much and how to treat physical and psychological violence in schools in teaching?

\section{Definitios}

* Violence is defined by the World Health Organization as the intentional use of physical force or power, threatened or actual use of it against yourself, another person or against a group or community that either results in or is likely to result in injury, death, psychological harm, or bed development power.

* Violence matter of law the recommendations of the Assembly of the Council of Europe can be considered as a violation (violation) of the total of all human rights, the right to life, safety, dignity and physical and mental integrity and can take different forms, or more accurately, materialized in various forms, such as aggression or assault, sexual abuse and rape, and the thrill of deep threat or intimidation and should be considered by the criminal law as a criminal offense.

* Violence is deliberate action to force another physical or psychological means, subject to the interests, goals and desires one. (K.Grillo)

* Violence is verbal expression, mimicry or pantonomi; behavior or action, conscious or not, of one or more individuals, in one or more individuals, to control, oppression, punishment and alienation change to another personality . (A.Deva-Zuna)

\section{Theoretical definitions of violence at school:}

* Bullying is aggressive behavior with a view to cause physical or psychological harm to another within educational institutions.

- Bullying includes:

- $\quad$ hitting the hallways, calling names, intimidation,

- food and money hijacking, suicide,

- forms of sexual harassment,

- behaviors among children and adolescents,

- $\quad$ systematic violence

* David Mayers social psychology researcher points out that because of aggressive behavior that brings reward aggression.

* According to Mayers children whose parents punishment tend to behave aggressively with others. Parents aggression have a way to deal with things.

* Violent behavior in schools dealing with the situation where young people are among the three different cultures or codes of behaviour home-school - way.

\section{General hypothesis:}

Violence against children in schools in the last decade Peshkopi is growing and it represents a new challenge not only to the school management, but also a big problem family, ethical, social.

\section{Auxiliary hypothesis}

a. In our school there are all ways, types and levels of physical and psychological violence

b. Causes school violence:

F. physiological, cultural, academic, personality, school climate.

The object of study: High School Gymnasium Maqellara and "Said Najdeni" Peshkopi, Albania, "Remzi Ademaj" Prizren, Kosovo, "28 November" Dibër , Macedonia parents, teachers, doctors, psychologists. 
Triangle cooperation between three actors: teachers, students and parents.

He manifests the existing situation.

Dotted lines indicate the current state of cooperation.

Contact is physically and uncooperative

Territory or personal space and unwillingness negligence action

If removed limits established an educational system safe against violence, teaching and learning and promising for the future.

Attitudes and beliefs about physical and psychological violence

First Position: physical and psychological violence, absolutely the most effective means of disciplining children.

The second attitude, physical violence causes many negative consequences on children.

Third position: violence can be positive effects.

The reasons for the use of violence against children

The philosophy of the benefit, which brings violence

Loss of self-psychology

The use of violence as an instrument of discipline.

Response to: disobedience, unrealized plans, lie, disagreement with one another, violating the rules, love, misunderstanding of the child.

\section{Forms of physical violence}

Use of violence as an instrument of discipline .

Disciplining children through the use of penalties is a known reality in daily life and scientific research .

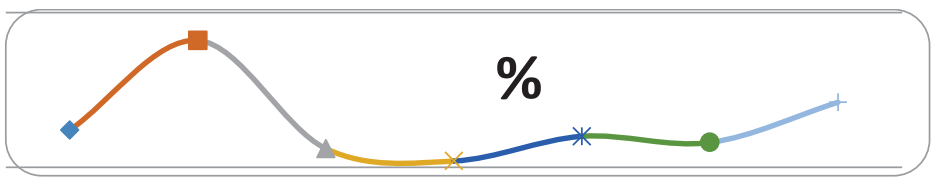

1.disobedience, 2.noise, 3.problems with grades, 4.excesses games

\section{Violence is in response to disobedience}

Violent teacher to give students lessons for their disobedience .

Discipline of students by legitimizing violence for violence disobedience. The abuser feels justified .Violence is in response to the non-realization of plans

Violence, which is used by teachers when a student has not academic outcomes .

Response to the violence lie

The violence of the occupation in response to each other pupils

Violence in response to love

Violence in response to misunderstanding

Consequences of violence against children

\section{Consequences of physical violence on children}

First conclusion : physical violence causing obvious physical 
$\square$ Teachers, parents and children in mass claim that violence obvious physical consequences : pain, certain injuries, and signs that remain after healing of injuries, , loss of physical abilities. Reports of fatal violence lacking.

$\square$ consequence of the violence is frequent bruises, bleeding, dizziness and loss of feelings .

$\square$ Physical violence is intertwined with violence and bullying psychological. Effects associated with severity of physical injury and the manner of its exercise .

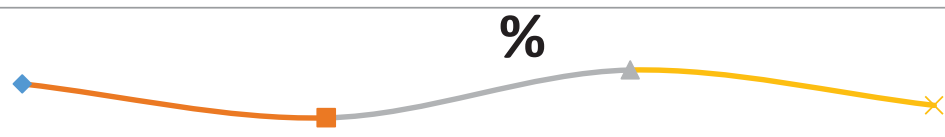

1.dizziness, 2.unconsciousness, 3.bruises, 4.bloodshed

\section{Physical Effects}

Second conclusion : Violence psychological consequences

Consequences affecting the overall level of emotional functioning of the child .

Consequences that affect child development opportunity

Cultivation of violent behaviour

\section{Third conclusion}

Teachers and parents are more aware of the physical effects than psychological consequences of violence against children . Physical consequences are visible and they promote feelings of repentance to users of violence. The awareness of the consequences of psychological violence is very low. Psychological violence is tolerated and its effects underestimated.

3. Thought about suicide as a result of violence

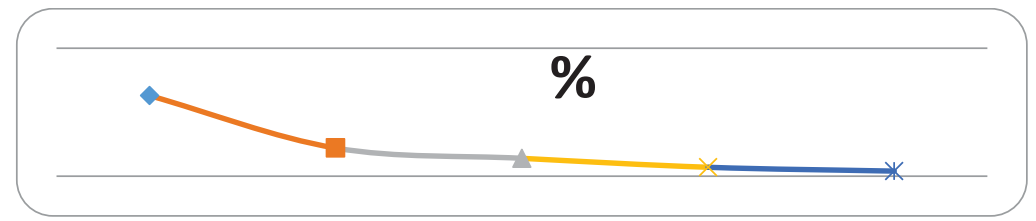

1.never 2.once 3.twice 4 .thrice $5.0 v e r$ three times

Schools are considered safe environments. We have made the difference between the perception of security and real security .

Real is real safety risk measures / no risk in school .

Security is a personal perception of the level of safety at school

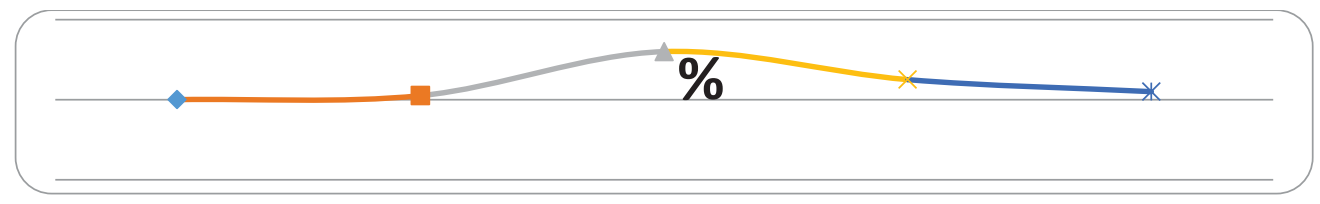

1.very safe,2. safe, 3.neither safe nor unsafe, 4. unsafe, 5.very unsafe 
4 : Level of safety at school as perceived by students

\section{Perpetrators of violence}

Teachers teaching staff are the ones that most often violate students both physically and psychologically .

Teachers rarely hunt, but have much stronger shock than teachers. Teachers exert more violence against schoolgirls that to students. Teachers violate more students than female students .

\section{The severity of violence .}

Some forms of physical violence are : assault with a punch to the head or body , forced collisions, collisions with the object , ...

Severe forms of physical violence used as the boys and the girls. However it is used more for boys .

Forms of bullying : stripping off, negative grading as punishment for bad behavior, slurs, nicknames, epithets, curses . It is used more to teachers and students .

\section{Alternative forms of disciplining children}

\section{$\square$ Keeping Rampage}

\The transfer of the child from a booster environment in a less amplifier .

\section{$\square$ Awards}

\ Removal of privileges

Cooperation trinomial teacher -student - parent to child positive change is minimal .

The prevailing trend of teachers attacked the child, who demonstrate problematic behavior rather than problematic behavior .

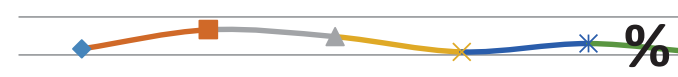

1. director, 2.teacher, 3.the parent, 4.psychologist,5. friend, 6.person himself

5 : Frequency of people have problems when run

\section{Forms of bullying}

About 60 percent of the population are Internet users. Facebook has 1.3 million users, or in other words more than $78 \%$ of the online population are active in social networks. If we analyse the data for the age of social networking users, it turns out that most of them are young people under 24 , under 18 , so $15 \%$ are $15-17$ years and $6 \%$ at age $13-15$ years.

Increased aggressiveness seen higher in boys aged 14-18 years.

$14 \%$ engage in "Teen Dating Violence"

Children should be educated in order to protect them.

Internet-violence is to model behavior and way of thinking. It increases the level of verbal and nonverbal aggression, beginning to manifest to other children or young peer

Media treats the phenomenon of violence that is used against children in episodic. It has left without cover more moderate forms of various types of violence against children and is interested in severe forms. In many cases, the print and electronic media has treated this phenomenon without observing professional ethics, so noisy and profit. 


\section{SWOT Analysis}

\section{Options}

Cooperation with associations, lifelong learning, licensed teachers, the school culture, the new high school curriculum .. professional potential, motivation of staff, education reforms, strategic plans, no ethnic discrimination, the school selfevaluation, ...

\section{Limitations}

Centralism AEM-RED-school, lack of psychologists, social administrators and security personnel, lack of activities, student government dysfunctional, untransparency , .... Lack of Child Advocate, incongruity traditional teachers, lack of information, lack of students in decision-making, and lack of training misuse their recently untransparency, ...

\section{Achievements}

Child code, public agencies reporting, psychological services, security personnel and psychologists, school uniforms, ...

\section{Risks}

Lack of facilities, poor success, abandonment, asocial and antisocial personality.

\section{Conclusions}

The absence of national legislation, national policies and structures consolidated.

Lack of readiness among professionals to talk about violence against children.

The low level of reported cases of violence due to weaknesses in the child protection system. Clear differences between sectors in terms of identification, registration, reporting and referral of violence. Low scores on tests of $\mathrm{MH}$.

\section{Recommendations}

Commitment and action to strengthen national and local levels.

Prohibit any kind of violence; all violence against children and prioritize prevention. To promote non-violent values and awareness raising.

To increase the capacity of all those staff who work with children.

Provide social services, psychological and counselling.

Establish reporting systems and services accessible and tailored to children.

Ensure participation of children.

Television is not a "baby sitter" - child care.

Society to be protected and not be influenced by material found in the media and Internet.

Reducing virtual time extracurricular activities for a real product.

Reformation of the school's mission: education and social role.

\section{References}

Biehler R- Snowman I, Psikologji e zbatuar në mësimdhënie, Nënë Tereza, Tiranë,2004

Jashari H, Sociologjia e arsimit, Interlingua, Shkup 2007

Kushtetuta e Republikës së Shqipërisë , Tiranë 1998

Kodi Penal i Republikës së Shqipërisë

Kodi i Procedurës Penale i Republikës së Shqipërisë

Murati Xh, Metodologjia e kërkimit pedagogjik, Çabej, Tetovë 
Shkurtaj Gj-Kazazi Nj-Çiraku Y, Hyrje në metodikën e punës shkencore, Shblu, Tiranë, 2004.

Tamo A- Karaj Th, Dhuna kundër Fëmijëve në Shqipëri, Tiranë 2006

Save the Children, Konventa mbi të Drejtat e Fëmijëve, Tiranë ,1992

UNICEF, Plani i komunikim për ndikimin mbi sjelljen (COMBI) për reduktimin e dhunës si disiplinë nga ana e mësuesit / kujdestarit ndaj nxënësve / fëmijëve në Shqipëri : Rritja e Praktikës së Rrugës së Re të Disiplinës (NWD) 2007-2011, Tiranë 2007.

www.crca.org.al

www.educationworld.com

www.savethechildren.net/alliance/index.html

www.unicef.org

www.unicef.org/teacher 